\title{
THE IMPLEMENTATION OF PANCASILA VALUES IN THE COUNSELING PHASE FOR NARRIPANTS IN NARCOTICS INSTITUTIONS CLASS III SAMARINDA
}

\author{
${ }^{1}$ Suryaningsi, a researcher from PS-PPKn FKIP Mulawarman University \\ ${ }^{1}$ Email:suryaningsi@fkip.unmul.ac.id \\ ${ }^{2}$ Venna Puspita Sari, Student Magister University of york, United Kindom \\ ${ }^{2}$ Emai: Vennapuspita@gmail.com
}

Received: 08 Oktober 2020; Revised: 21 November 2020; Accepted: 28 Desember 2020 DOI: http://dx.doi.org/10.37905/aksara.7.1.19-28.2021

\begin{abstract}
This scientific paper aims to identify and describe the values of Pancasila which are still implemented in the guidance phase for prisoners in the Class III Narcotics Penitentiary in Samarinda. Using research methods with this type of qualitative research approach description. The target data were obtained from primary data sources, namely, 9 respondents consisting of the Head of the Institute, Corrections (Kalapas), the Head of the Development Sub-Section, (Head of Development Sub-Section), Development Staff and Prisoners. Secondary data obtained directly, data collection techniques using observation, interviews, and documentation. The data obtained are then collected and reduced, displayed then take conclusion action. The results showed that the values of Pancasila are applied in correctional institutions as a guide in the life of the nation and state. Especially the implementation of the second principle of Pancasila values, namely a just and civilized humanity. Fair and civilized human values are an achievement of the awareness of moral attitudes and human behavior based on individual human potential. As it ensures the stability of the necessities of life, the balance between personal life and life together. The values of tolerance, mutual respect, equality of rights and obligations, and cooperation contained in fair and civilized human values have been implemented even though their application is minimal in the field. It is necessary to increase implementation, especially in terms of carrying out the value of tolerance between religious communities, carrying out humanitarian activities, mutual respect, implementing justice for equality of rights and obligations, and establishing the value of cooperation without any basis for differences.
\end{abstract}

Keywords: Correctional Institutions, Guidance,Narcotics, Pancasila Value.

\section{INTRODUCTION}

The success of national development is largely determined by human resources. Human resources need special attention, both by the government and the community itself. Changes that occur in Indonesia and the world are so very fast, that it causes all 
life orders to change while a new life order has not yet been formed. This is because the joints of life have been considered obsolete. The values that become life models have lost their authority so that humans become confused in determining their life goals. To respond to this condition, the government needs to anticipate that it does not lead to a very concerning situation.

Ideology is a strong and solid foundation for a nation to solve these problems. Ideology as a view of life for the nation is the framework for the value system that is lived and owned by society. According to (Syarbaini, 2009), philosophically the value of Pancasila is a way of life. Thus Pancasila is used as a guide in behaving and acting in all areas of life, including the fields of economy, politics, socio-culture, and defense and security. Therefore, Pancasila must be implanted or passed on to the entire Indonesian nation.

The values contained in each of the Pancasila principles are highly respected by the Indonesian people because they are the identity of the Indonesian nation.

Pancasila, especially the second principle, teaches that the Indonesian nation can humanize humans when someone is having a problem, the solution is with fair and civilized humanity. this is inseparable from human nature as the being of God Almighty, as a social being, so the appreciation and practice of Pancasila values will be determined by humans themselves so that they can control themselves and their interests to understand their rights and obligations as citizens of Indonesia.

The correctional system is an arrangement regarding the direction and boundaries and methods of fostering prisoners based on Pancasila which is carried out in an integrated manner between the supervisor, the assisted residents, and the community. This is done to improve the quality of prisoners to be aware of mistakes, improve themselves and not repeat criminal acts so that they can be accepted back by the community, can actively play a role in the development and can live naturally as good and responsible citizens.

Criminal and criminal problems in their history have always changed. The theory adopted in the prison system places the inmates as subjects and is seen as individuals and ordinary citizens, and is faced not with a background of retaliation but with guidance. As said (Saragih, 2018):

"The prison system adopted by Indonesia, regulated in Law Number 12 of 1995 Concerning Corrections, this is a change of ideas juridical and philosophical from the prison system to the penitentiary system."

(Barda Nawawi Arief, 2018) also states:

"Starting from the idea that crime is essentially only a tool to achieve an objective, the concept first formulates the purpose of punishment. In identifying the purpose of punishment, the concept starts from the balance of 2 (two) main targets, namely protection of the community and protection or fostering of individual perpetrators of criminal acts. " 
The purpose of criminalization in Indonesia must consider a theoretical framework that is truly in line with the philosophy of life of the Indonesian people based on Pancasila and the 1945 Constitution, namely basing oneself on balance, harmony, and harmony between social and individual life.

The integrative theory of the purpose of punishment is a combination of various theories of the purpose of the punishment which are considered more suitable for application in Indonesia, of course by using a sociological, ideological, and philosophical juridical approach, which is based on the assumption that criminal acts are a disturbance to the balance, harmony, and life of the community.

Correctional Institutions (Lapas) are institutions created by the state to transform criminals or criminals into good citizens. By entering the Penitentiary a criminal gets intervention in the form of education in various fields so that after undergoing his "redemption" period it is hoped that he can return to life in the community and no longer commit acts that violate the law (Maulani, 1999). Prison is a "school" so that former prisoners become new individuals who are more responsible.

Counseling, mental spiritual education (religion), formal education, and skills are provided by the state to prisoners. Correctional Institutions provide the cultivation of new values or brainwashing so that prisoners can live normally according to social norms and state regulations. Providing education and skills to prisoners in correctional institutions is one of the interventions to equip them to be able to live normally again so they don't repeat their actions (Jaya, 2012).

However, in reality, there are still many imbalances in the activities of guiding residents of prisons in prisons. Based on the results of the author's observations at the Class III Narcotics Penitentiary, Samarinda, many coaching activities are still not running optimally, both in the religious, intellectual, attitude and behavior, professional aspects, as well as the physical and spiritual health of the correctional clients.

The various problems above, the writer focuses on the aspects of developing attitudes and behavior. Not going to prison again is a measure of the success of the transformation process in the Penitentiary. However, the cases that occur show the opposite, many prisoners after leaving prison continue to carry out their old actions. This is what is called the occurrence of the criminal cycle, where the prison is not able to make prisoners become good citizens, even in some cases, they become increasingly skilled at committing crimes.

The detachment of these ex-convicts has made the police in Indonesia always "tinker" to monitor the recidivists because there is a tendency for their illnesses to recur. This can be seen from the drug abuse crime case. Many drug users are recaptured after a few months out of prison.

Based on the data obtained from the author's observations, there are still 31 recidivists in the Class III Narcotics Penitentiary in Samarinda. However, this fact cannot 
be used as an excuse to eliminate the function or close down correctional institutions in Indonesia. In some cases, the Penitentiary can transform a criminal into a good citizen.

It becomes a big question mark on the function of the Penitentiary. Where we all know that in this institution, prisoners get a lot of guidance even before leaving prison, in the phases that they go through, all have a role in being able to restore the prisoner's function when returning to society.

Even in the last phase in the Penitentiary where prisoners undergo a phase of assimilation and guidance. The guidance that is carried out also focuses on the selfreliance of the prisoners. The guidance is expected to improve the quality of devotion to God Almighty, Intellectuals, Attitudes and Behaviors, Professionalism, and Physical and Spiritual Health. Attitudes and behavior by the second principle of Pancasila, namely fair and civilized humanity become a basic benchmark.

\section{RESEARCH METHODS}

The type of research used in this research is descriptive qualitative research. "This descriptive type aims to make systematic, factual, and accurate descriptions of the facts and characteristics of certain populations or objects", (Tri Ramdani, 2014). This study discusses the pattern of guidance in the attitude and behavior guidance phase for Class III Narcotics Prisoners in Samarinda.

The research was conducted at the Class III Narcotics Penitentiary in Samarinda, which is located at Jalan Solid Karya, Kelurahan Sempaja Utara, Kecamatan Samarinda Utara, Kota Samarinda, East Kalimantan. According to the opinion (Rahardjo, 2017), what is meant by data sources is the data subject from which the data is obtained to find out who is used as a source. To obtain the data needed in this research, it can be done by interview, observation, and documentation. (Saepudin, 2011), defines that the data source in research is the subject from which data can be obtained. Determination of respondents and research informants using technique purposive sampling. As stated by (Caputi, 2003) that purposive sampling is a technique for data sources with certain considerations.

This particular consideration, for example, the person is considered to know best about what we expect or as a Correctional Officer so that it will make it easier for researchers to explore the object of research or the situation to be studied. Technique Purposive Sampling, also stated by (Creswell, 1394) that the goal is to obtain a sample of people who meet predetermined criteria.

Sources of data can be divided into two types, namely: 1. Primary Data Sources: According to (Neuman, 2003) Primary data sources are data sources obtained directly from the source, observed and recorded for the first time, using-depth interviews. 9 respondents were consisting of the Head of the Institution, Corrections (Kalapas), the Head of the Development Sub-Section, (Head of Development Sub-Section), Coaching Staff, and Prisoners. 2. Secondary data sources are data that are not collected by 
researchers themselves. So secondary data comes from the second, third hand, and so on. This means passing through one or more parties who are not researchers (Mamchych et al., 2002). Secondary data sources in this research are data from correctional institutions, scientific journals, books, internet references, and so on.

Data collection techniques, according to (CR Kothari, 2003) data collection techniques are the most strategic steps in research because the main purpose of the research is to obtain data, observation; Interview; and Documentation. Data validity is done through triangulation, which is the most commonly used method of ensuring the validity of data in qualitative research. Triangulation is a technique of checking the validity of data by utilizing something other than the data for data checking purposes or as a comparison to the data.

Analysis Techniques used in this study are interactive analysis. This model has 4 components of analysis, namely: data collection, data reduction, data presentation, and concluding. According to (Caputi, 2003), "Data analysis is the process of organizing and sorting data into patterns, categories, and basic description units so that themes and places can be formulated working hypotheses as suggested by the data". The data analysis steps according to Miles and Huberman in the book (Kurniadi, 2011), are as follows: Data collection; data reduction; presentation of data, and concluding.

\section{RESULTS AND DISCUSSION}

\section{Results}

\section{a. Inter-Religious Tolerance The}

a consequence of social life is tolerance. The tolerance that the author means here is tolerance between religious communities. Tolerance is an attitude of accepting differences between oneself and others. This is by the presentation of the Constitutional Court (Kalapas) namely: "Religious tolerance is an attitude of being aware of the differences in beliefs held by each person and willing to accept these differences." (27 November 2019).

Tolerance between religious communities is an absolute value that must be applied in the life of the nation and state. Even in prisons, we must protect these values for the common welfare. As for the application of the value of tolerance between religious communities that occurs in prisons as conveyed by HS (Coaching Staff): "For its implementation, Alhamdulillah it has gone well. We give them freedom of worship and do not discriminate. When Christians are celebrating their religious day, we facilitate it. Likewise with Muslims. " (08 December 2019).

The implementation of inter-religious tolerance activities at the Samarinda Narcotics Prison has been going well. Many activities reflect this, for example participating in helping each other to prepare for religious activities despite different beliefs. 


\section{b. Conducting Humanitarian Activities}

Humans are individual and social creatures. It is a basic requirement for every human being to interact with other humans. Likewise, with prisoners, officers must meet the needs of prisoners to socialize. The following is the description of ES (Coaching Staff) related to humanitarian activities that are often applied in fostering the attitudes and behavior of prisoners in the mentoring phase:

"We usually do social activities both inside and outside prisons. We give priority to social activities in (Lapas) because there are several considerations from a security perspective. So with them socializing between prisoners, with officers, and with several sources is enough and easier in terms of supervision. " (18 December 2019).

Social activities that are implemented by officers are more directed to the guidance in prisons. This is by what was conveyed by HT (Prisoners) that:

"Social activities here are cleaning the mosque because when entering the $2 / 3$ period, on average they follow the integration program. So based on PP. 99 of 2012, which is prisoners must recite for religion as a condition of assimilation. There is no assimilation outside, everything is inside. "

Humanitarian activities in fostering attitudes and behavior have gone well where these activities aim to shape the value of cooperation and cooperation in humanity. There are several activities implemented, namely internal and external prison social activities (cooperation with external parties). However, based on information from several sources, social activities, especially for assimilation, are only applied in prisons, by bringing third parties into prisons.

\section{c. Respecting each other in}

Narcotics Prisons, prisoners are required to be able to live in a society with other prisoners. For this reason, prison officers need to develop an attitude of mutual respect between prisoners. According to MH (Coaching Staff), the description of the value of mutual respect is as follows: "Mutual respect does not disturb or create a fuss, it includes respecting friends (among prisoners)." (06 December 2019).

Meanwhile, IS (Prisoners) who agreed with MH's statement (Coaching Staff) added: "Mutual respect is applied in this prison, such as not offending others, speaking politely, joking, there are also limits. There is one who is worshiping, the other is not worshiping so they are silent and do not interfere. " (December 22, 2019). Not only between prisoners but also the attitude of mutual respect by officers to prisoners by what was conveyed by $\mathrm{T}$ (Head of Development) that:

"The older respects the young, and the young respects the old. It is the same as officers and prisoners, namely respecting each other and guarding each other so that they are not arbitrary in acting and speaking. So that this will have an impact on the coaching process to run well. " (20 November 2019). The application of the value of mutual respect in fostering attitudes and behavior of prisoners in the guidance phase, namely carrying out and implementing what activities are believed to be for mutual comfort. So 
far it has gone well, where the implementation has been seen to be carried out by officers and prisoners, whether it is in the form of moral values, as well as behavior and behavior, both officers and prisoners.

d. Equal Rights and Obligations of the correctional system, Prisoners have the right to receive spiritual and physical guidance and are guaranteed their rights to carry out their worship, communicate with outsiders both family and other parties, obtain information both through print and electronic media, receive a proper education, and so on. This is stated in Law No. 12 of 1995 regarding correctional facilities, as stated by T (Head of Sub-Section for Development) that:

"Prisoners' rights are almost the same as human rights in general, such as the right to food, the right to health, the right to worship, the right to education, and so on. What differentiates them from other human beings is their right to freedom which we silence. The rest, we give them their rights according to the mandate of the correctional law. " (30 November 2019).

The same statement was also made by TS (Prisoners): "We get a lot of rights, such as the right to remission, the right to food, the right to health services, family visits, and many more." (27 December 2019). In addition to having given the prisoner's rights, the consequence that must be borne by the prisoner is to comply with the obligations set by the officer. T (Kasubsi Guidance) stated that:

"All prisoners must maintain security and follow the coaching program." (30 November 2019). The rights of prisoners that are applied by officers during the coaching process are classified as many, including the right to get remission, visitation rights, worship rights, health rights, food rights, and others. Also, the obligations of prisoners that have been implemented, including maintaining security and following all activities and programs of coaching activities, even though they have not run optimally.

e. Collaboration

Coaching activities implemented by officers foster a lot of positive values for prisoners, one of which is cooperation. Coaching activities implemented by officers to increase the value of cooperation among prisoners are as conveyed by HS (Coaching Staff) as follows: "Almost all coaching activities build cooperation between prisoners. For the most basic activity is a religious activity. Then sports activities also make them synergize with each other. In essence, all activities are oriented towards building prisoners so that they are more active and have a social spirit. " (08 December 2019). The same thing was conveyed by TS (Prisoners):

"All coaching activities that we do are classified as cooperation, for example in cleaning each room, exercising, even eating requires cooperation in the collection. Because if here (Lapas) does not cooperate, it will be difficult on their own in the future. " (27 December 2019). The value of cooperation that is applied in fostering the attitudes and behavior of prisoners in the guidance phase has been running well, including through religious activities, cooperation, providing food, and sports activities. The benchmarks 
for indicators of success in activities are seeing the extent of participation, participation, and achievements achieved by prisoners to be able to increase the value of cooperation.

The results of interviews from 9 respondents consisting of several officers and prisoners at the Class III Narcotics Prison in Samarinda show that fair and civilized human values are a goal or achievement and hope that has always been carried out in every coaching process at the Class III Narcotics Prison, Samarinda. As for the implementation, namely carrying out the value of tolerance between religious communities, carrying out humanitarian activities, mutual respect, implementing justice for equality of rights and obligations, and establishing cooperation. Hope for the future to create an attitude and moral awareness for prisoners.

\section{Discussion}

Fair and civilized human values are the values of awareness of moral attitudes and human behavior based on the potential of the human conscience about norms and culture in general, both towards oneself, fellow humans, and the environment.

Tolerance between religious communities is an attitude of appreciating and accepting all kinds of differences with a sincere heart between all differences and the dynamics of religious communities. The human values that become the foundation in its implementation can run according to what is expected, including creating an atmosphere of cooperation, cooperation, and mutual respect or respect for various kinds of differences in the treasury of each individual and society.

Even in prisons, tolerance between religious communities should be cultivated. As a godly country, an equitable understanding of religious diversity must also be applied. The informant's justification refers to the running of religious activities in prisons which illustrates that among prisoners can accept the existence or existence of people of other religions. In other words, prisoners are required to have a social spirit.

The social spirit is a common thing that is owned by humans, considering their nature as an individual being and a social being. For this reason, the right to social life needs to be fulfilled by officers. The right for prisoners to have a society is stipulated in the Republic of Indonesia Government Regulation Number 99 of 2012 concerning Terms and Procedures for the Implementation of the Rights of Correctional Assistants, namely through the assimilation program. The assimilation program is given to prisoners who have served $2 / 3$ of their detention period with a record of good behavior and actively participating in the coaching program.

In general, assimilation is carried out outside prisons with the hope that prisoners can reintegrate into society, and build a community paradigm that prisoners can compete again in the world of work. However, in practice at the Class III Narcotics Prison, Samarinda, according to some informants, the assimilation program was justified in the prison area itself. 
This condition becomes a dilemma because on the one hand the social activities are carried out in the prison area on the pretext of maintaining security and facilitating supervision by officers. If we examine further, prisoners who have entered the $2 / 3$ prison term should have matured from a personal perspective as an effect of the guidance program that has been implemented by officers.

Social activities are held so that prisoners can return to living in society. This means that prisoners can apply mutual respect for one another. Mutual respect is an attitude where we treat someone appropriately and accordingly. In everyday life, this attitude of respect is very important because it is a good character for humans as social beings. Where we have to interact well with others.

On the other hand, equal rights and obligations are the next important point in the process of fair and civilized human values. The rights of prisoners which are applied by officers during the training process have been adjusted to Law No. 12 of 1995 concerning Penalty, including the right to get remission, visitation rights, worship rights, health rights, food rights, and others.

Along with the rights of prisoners, some obligations become a consequence of fulfilling these rights. Prisoners' obligations that have been running by Law No. 12 of 1995 concerning Corrections, including maintaining security and participating in all activities and coaching programs. In implementing the fulfillment of the rights and obligations of prisoners, there is a synergistic relationship between officers and prisoners and even among prisoners themselves. Cooperation between the two parties is needed to realize the realization of equal rights and obligations. The value of cooperation is grown by officers through several prisoner development programs.

According to (Warsito, 2018), regarding this theory that: Criminalization is not retaliation for the perpetrator's mistakes but a means of achieving a useful goal to protect the community towards the welfare of the community. Sanctions are emphasized on their purpose, namely to prevent people from committing crimes, so they are not aimed at absolute satisfaction of justice.

Fair and civilized human values in which the values of tolerance, cooperation, mutual respect, and equality of rights and obligations in the future, the prisoners will become human beings who benefit the community towards prosperity.

The return of prisoners to social order is a must for prisoners. This is a form of justice that prisoners deserve when they become fully human beings, who are aware of the importance of obeying norms in society (Yunus, 2014).

This contradicts the theory of justice (Rawls, 1997) which emphasizes social justice, which is associated with the emergence of conflicts between individual interests and state interests. If the social rights of prisoners are narrowed, then the justice obtained by prisoners is minimal. This is what makes the development of prisoners not able to be said to be running optimally. 
Fair and civilized human values that can be implemented and focus on guaranteeing the stability of life and the balance between personal life together through the values of tolerance, cooperation, mutual respect, and equal rights and obligations.

These values can be maximally implemented if the needs of prisoners have been met. Officers must meet the needs of prisoners during their prison term. In line with the theory of needs initiated by (Maslow, 1999), his theoretical concept explains a hierarchy of needs that shows the existence of five levels of human wants and needs which include physiological, security, social, reward, and self-actualization needs.

The psychological needs of prisoners have been fulfilled but are still minimal, for example, the residential rooms occupied by prisoners. Based on the data obtained by the author, the prison capacity is for 352 prisoners, but it is filled by 1354 prisoners. It is conceivable that the need for Prisoners' boards is very limited. Likewise with other needs that are still minimally applied. The values of tolerance, mutual respect, equality of rights and obligations, and cooperation embodied in fair and civilized human values have been implemented according to the hierarchy of needs even though their application in the field is minimal and gradual.

Fair and civilized human values are an achievement of the awareness of moral attitudes and human behavior based on individual human potential. As for in, it ensures the stability of the necessities of life, the balance between personal life.

\section{CONCLUSION}

The implementation of Pancasila values which is manifested is the second principle, namely a genuine and civilized humanity. Fair and civilized human values are an achievement of the awareness of moral attitudes and human behavior based on individual human potential. As it ensures the stability of the necessities of life, the balance between personal life and life together. The values of tolerance, mutual respect, equality of rights and obligations, and cooperation contained in fair and civilized human values have been implemented even though their application is minimal in the field. It is necessary to increase implementation, especially in terms of carrying out the value of tolerance between religious communities, carrying out humanitarian activities, mutual respect, implementing justice for equality of rights and obligations, and establishing the value of cooperation. Even though fair and civilized human values have become a goal or achievement and hope that has always been carried out in every process at the Class III Narcotics Prison, Samarinda. 